\title{
Towards connecting green economy with informal economy in South Africa: A review and way forward
}

\author{
Suzanne Smit ${ }^{* 1} \&$ Josephine K Musango ${ }^{2}$ \\ ${ }^{*}$ Corresponding author: Suzanne Smit
}

${ }^{1}$ Student, Master's in Sustainable Development, School of Public Leadership, Stellenbosch University; Address: 4 Pinotage Avenue, Somerset West, 7130, South Africa

${ }^{2}$ School of Public Leadership, and the Centre for Renewable and Sustainable Energy Studies (CRSES),

Stellenbosch University; Private Bag X1, Matieland 7602, South Africa 
1 The informal economy is a vibrant and growing phenomenon, offering both

2 opportunities and lessons on resilience and innovation. When considering global

3 social, economic and environmental challenges, resilience and innovation are

4 valuable response strategies. The notion of a green economy has similarly inspired a

5 number of ideological, geopolitical and institutional responses, yet a review of the

6 dominant approach indicates the propensity to undervalue or ignore the informal

7 economy. Within the context of sustainable development and poverty eradication,

8 connecting the informal economy with the green economy is imperative. This paper

9 explores possible connections between the green economy and the informal economy

10 in South Africa and argues that by engaging the informal economy in discussions on

11 the green economy, a more informed policy and planning environment may ensue,

12 resulting in more socially equitable and environmentally sustainable development.

13

14 Keywords: green jobs; inclusive green economy; green growth; informal economy;

15 second economy; South Africa 


\section{Introduction}

Though difficult to define, the informal economy is visible in different guises ranging from survivalist business activities being run from pavements, pedestrian malls, transport interchanges and homes, to agrarian activities found in both urban and rural areas. The informal economy relates to 'economic activities by workers and economic units that are - in law or in practice - not covered or insufficiently covered by formal arrangements' (ILO, 2003). Various terminologies are used synonymously with the term 'informal economy', including informal sector, second economy, informality and shadow economy (Rogerson, 2007). The informal economy plays an important role in the overall economy of a country. In fact, for many countries across the globe, the informal sector employs more persons than the formal sector (ILO, 2012). For instance, in sub-Saharan Africa, the informal economy accounts for up to $72 \%$ of employment, rendering it significant in the context of sustainable development and poverty eradication (Dawa \& Kinyanjui, 2012). In Brazil and India, the proportion of persons employed in the informal economy is $42.2 \%$ and $83.6 \%$ respectively. This is much higher in comparison with South Africa, which is $37.2 \%$ (ILO, 2012). However, the sector still plays an important role in the share of employment in various economic activities (ILO, 2012). The importance of the informal economy to the urban and rural poor, and especially to women, is also acknowledged (Chambwera et al., 2011).

Despite the above benefits, the informal economy poses a number of social, economic, environmental and political challenges worldwide; many of which remain under-unexplored (e.g. Dreher \& Schneider, 2010; Buehn \& Schneider, 2012). Of particular interest to this paper are the recent discussions on the need to acknowledge 
41 the informal economy in the green economy agenda (e.g. Dawa \& Kinyanjui, 2012).

42 Solutions need to be found to questions such as: Can the informal economy contribute

43 to a green economy? or Can the green economy be planned in such a way that it will

44 help provide solutions to the challenges that dominate in the informal economy?

46 As a starting point to addressing the above questions, the authors undertook a critical 47 literature review to (i) provide a macro perspective and understanding of the green 48 economy landscape; (ii) understand the reality of a green economy in South Africa; 49 (iii) trace various perspectives and approaches to 'managing' the informal economy; 50 and (iv) identify the role and value of the informal economy to sustainable 51 development and a green economy.

\section{2. Global perspectives and pathways for a green economy}

54 The transition to a green economy is well on its way, yet several issues hinder its 55 conceptualisation and implementation (UNDESA, 2014). These issues also impact the 56 realisation of an 'inclusive green economy' and are expanded on in the following 57 section.

\subsection{Issues of divergent definitions and principles}

60 The many definitions for 'green economy' are indicative of the myriad of approaches

61 to and perspectives on what should be 'greened' and how that could be done. Initial 62 definitions of the green economy indicated little emphasis on the social dimension of 63 sustainable development (Allen, 2012). To address emerging concerns, the concept 64 was redefined at Rio +20 , expanding the concept to 'inclusive green economy' and 
65 'inclusive green growth', whilst situating the green economy 'in the context of

66 sustainable development and poverty eradication' (Allen, 2012).

67

\subsection{Aspects of power and participation}

Despite efforts to redefine the green economy, concerns remain as to how the social

dimension is interpreted and applied. Cook et al. (2012), for example, problematise narrow interpretations of stakeholder engagement. The green economy is also

economy (Dawa \& Kinyanjui, 2012).

According to Cook et al. (2012), further contestations about the green economy relate approaches are not necessarily distinct and there are some overlaps. However, the market-liberalist approach championing green growth is recognised as dominating the international stage (Clapp \& Dauvergne, 2011).

82

Table 1: Dominant approaches and transition pathways to a green economy

\begin{tabular}{|c|c|c|c|c|}
\hline & Green Growth & $\begin{array}{l}\text { Strong } \\
\text { Sustainability }\end{array}$ & $\begin{array}{l}\text { Social } \\
\text { Economy }\end{array}$ & $\begin{array}{ll}\text { Limits } \\
\text { Growth }\end{array}$ \\
\hline Worldview & Market liberal & Institutionalist & Social green & Bioenvironmental \\
\hline Social & $\begin{array}{l}\text { Green jobs } \\
\text { Social protection } \\
\text { for vulnerable } \\
\text { groups } \\
\text { Equality of } \\
\text { opportunity } \\
\text { Stakeholder } \\
\text { consultation } \\
\text { Green consumerism }\end{array}$ & $\begin{array}{l}\text { Global } \\
\text { cooperation } \\
\text { Redistribution } \\
\text { (income) } \\
\text { Stronger } \\
\text { institutions } \\
\text { Inter- and intra- } \\
\text { generational } \\
\text { equity } \\
\text { Capacity building } \\
\text { Social dialogue }\end{array}$ & $\begin{array}{l}\text { Redistribution } \\
\text { (income, wealth } \\
\text { and power) } \\
\text { Rights-based } \\
\text { Social justice } \\
\text { Equality of } \\
\text { outcomes } \\
\text { Empowerment } \\
\text { Citizen action }\end{array}$ & $\begin{array}{l}\text { Radical decrease in } \\
\text { consumption and } \\
\text { population growth } \\
\text { Inclusivity } \\
\text { Needs }\end{array}$ \\
\hline
\end{tabular}




\begin{tabular}{|c|c|c|c|c|}
\hline Environmental & $\begin{array}{l}\text { Eco-efficiency } \\
\text { Technology } \\
\text { transfer } \\
\text { Reducing } \\
\text { Emissions from } \\
\text { Deforestation and } \\
\text { Forest Degradation } \\
\text { (REDD) }\end{array}$ & $\begin{array}{l}\text { Eco-regulation } \\
\text { Strengthen global } \\
\text { governance } \\
\text { regimes } \\
\text { REDD+ }\end{array}$ & $\begin{array}{l}\text { Environmental } \\
\text { justice } \\
\text { Agro-ecology } \\
\text { Grassroots action }\end{array}$ & $\begin{array}{l}\text { Eco-centric valuing } \\
\text { of nature for its } \\
\text { own sake } \\
\text { Enforced } \\
\text { regulation of global } \\
\text { commons }\end{array}$ \\
\hline Economy & $\begin{array}{l}\text { Green growth } \\
\text { Voluntary } \\
\text { Corporate Social } \\
\text { Responsibility } \\
\text { (CRS) } \\
\text { Carbon markets, } \\
\text { Payment for } \\
\text { Ecosystem Services } \\
\text { (PES) } \\
\text { Production focused } \\
\text { Private governance }\end{array}$ & $\begin{array}{l}\text { North-South trade } \\
\text { reform } \\
\text { Green finance } \\
\text { Green taxes } \\
\text { State Governance } \\
\text { Clean } \\
\text { Development } \\
\text { Mechanism } \\
(\text { CDM) }\end{array}$ & $\begin{array}{l}\text { De-globalization } \\
\text { Localization } \\
\text { Institutional } \\
\text { reform } \\
\text { Regional } \\
\text { solidarity }\end{array}$ & $\begin{array}{l}\text { No-growth/de- } \\
\text { growth } \\
\text { Measures beyond } \\
\text { GDP }\end{array}$ \\
\hline $\begin{array}{l}\text { Indicative } \\
\text { organizations }\end{array}$ & $\begin{array}{l}\text { World Trade } \\
\text { Organization } \\
\text { (WTO), } \\
\text { International } \\
\text { Monetary Fund } \\
\text { (IMF), } \\
\text { World Business } \\
\text { Council for } \\
\text { Sustainable } \\
\text { Development } \\
\text { (WBCSD) }\end{array}$ & $\begin{array}{l}\text { UNEP, United } \\
\text { Nations } \\
\text { Framework } \\
\text { Convention on } \\
\text { Climate Change } \\
\text { (UNFCCC), } \\
\text { Global } \\
\text { Environment } \\
\text { Facility }\end{array}$ & $\begin{array}{l}\text { World Social } \\
\text { Forum } \\
\text { Third World } \\
\text { Network }\end{array}$ & $\begin{array}{l}\text { World Watch } \\
\text { Institute, } \\
\text { Pachamama }\end{array}$ \\
\hline
\end{tabular}

Source: Compilation by Cook et al. (2012) drawing on Clapp and Dauvergne

For Söderbaum (2013), the dominant approach appears problematic, as it is underpinned by neoclassical economics that tend to be intolerant of alternative modes of thinking, thus negating true democracy. Söderbaum (2013) accordingly argues that

89 a broadened dialogue and a 'pluralism of perspectives' are required to confront issues of power and participation.

\subsection{Issues with related concepts}

93 The concepts of green economy, green growth and low-carbon development have

94 diverse origins, yet over time their meaning and use have become analogous in 95 economic decision-making and planning (Allen \& Clouth, 2012). However, these 96 concepts are contested on several fronts. The first one relates to relying on market 
97 based solutions for the green economy. These have been criticised for reinforcing 98 inequalities and power structures (Smith, 2011; Cook et al., 2012); commodifying the

99 commons and creating corporate capture (Boehnert, 2013); and for creating 100 disincentives for reconfiguring unsustainable production and consumption patterns 101 (Smith, 2011; Cook et al., 2012). The second one relates to certain assumptions 102 underpinning the logic of the green growth approach that are considered to be 103 integrally inadequate and weak (Smith, 2011). Green growth is viewed as a solution 104 to poverty (Allen \& Clouth, 2012) and while acknowledging the importance of 105 economic growth for any large-scale poverty reduction, Dercon (2012) warns of the 106 existence of trade-offs that increase social costs. Hence, if not explicitly addressed, 107 green growth may not be good for the poor. Thirdly, is the continued use of gross 108 domestic product (GDP) as measure of progress. Several authors suggest that GDP is 109 an inadequate and inappropriate measure for sustainable development, and therefore 110 should be adjusted, supplemented or replaced (Schepelmann et al., 2010; Daly, 2011; 111 AtKisson, 2013).

\subsection{Issues of design, implementation and review}

114 Few nations have created national green economy strategies as many are challenged 115 by institutional capacity, financing and integration issues (Allen, 2012; AtKisson, 116 2013). Countries that pursue a green economy as prompted by their National 117 Sustainable Development Strategies (NSDS) indicate similar challenges (Allen, 118 2012). 


\section{The South African green economy perspective}

121 South Africa recognises the green economy as a pathway to sustainable development

122 (DEA, 2014). It is party to several international conventions and agreements that are 123 related to sustainable development, and has successfully engaged with multiple 124 international green economy initiatives (Allen, 2012; Montmasson-Clair, 2012).

126 At national level, a number of key texts are identified as guiding the development of a 127 green economy in South Africa (Montmasson-Claire, 2012; DEA \& UNEP, 2013). 128 There are also a number of sector- and time-specific policies, as well as provincial 129 and local government initiatives and plans that support and complement the South 130 African green economy framework (Montmasson-Claire, 2012; Sustainlabour, 2013; 131 DEA \& UNEP, 2013).

133 Furthermore, the New Growth Path released in 2010 prioritises the green economy as 134 a 'job-driver' and as including activities that 'must provide an important entry point 135 for broad-based black economic empowerment, addressing the needs of women and 136 youth entrepreneurs and offering opportunities for enterprises in the social economy' 137 (EDD, 2010).

138 This would suggest that South Africa considers the green economy as an opportunity 139 to simultaneously address several socio-economic issues related to poverty, social 140 justice and equality; therefore aiming to achieve an 'inclusive green economy'. The 141 transition to an 'inclusive green economy' in South Africa however presents two main 142 challenges. Firstly, the institutional arrangements regarding the green economy are 143 complex and they involve a range of national and sectoral departments and 144 institutions. The complexity of these arrangements is indicative of the challenges to 
145 creating coherent responses to the 'what', 'how' and 'by whom' of the green economy 146 transformation. In particular, the responses tend to be fragmented and uncoordinated 147 (Montmasson-Clair, 2012; Nhamo, 2013), thus calling for efforts to systematically 148 coordinate both horizontal and vertical governance structures.

150 Secondly, there are vested interests, power relations and hegemonic regimes involved. 151 Numerous stakeholders influence how the green economy is conceptualised and 152 implemented. These forces and regimes operate at various levels and are influenced 153 by, for instance, internal party politics (Southall, 2010) and the minerals-energy 154 complex (Peter \& Swilling, 2011). Such influences ultimately limit the interpretation 155 and implementation of the green economy in South Africa to a narrowly focused, 156 market-liberalist approach.

158 Given the above constraints and challenges, there is a need for greater participation in 159 and a wider formulation of what an 'inclusive green economy' for South Africa may 160 be. The country's green economy transition thus should be analysed in terms of 161 'what' or 'whom' is included or excluded, and 'where' efforts are focused.

163 At first glance, the country seems to promote extensive social participation in the 164 development of the green economy. However, the level of public participation in 165 drafting the key texts that guide the implementation of the green economy vary from 166 limited to extensive (Montmasson-Claire, 2012), indicating lapses in consistency.

168 Several reports track the progress and potential of green jobs and the green economy 169 in South Africa (Maia et al., 2011; Montmasson-Claire, 2012; DEA \& UNEP, 2013; 
170 Sustainlabour, 2013). The general focus of these reports and their conceptualisation of

171 green jobs are limited to specific economic sectors in the formal economy. These

172 reports indicate very little engagement with the informal economy, thus implying that

173 future policies and plans for a green economy may also be limited in their 174 consideration of the informal economy.

\section{Perspectives on the informal economy}

177 Conceptually, the notion of the informal economy has a number of different 178 definitions and interpretations that impact upon data collection and measurement of 179 its size and monetary value. The economic activities taking place in the informal 180 economy are mostly unrecorded and therefore difficult to measure (Chen, 2012; 181 Wills, 2009). Further issues affecting accurate estimates of the size and contribution 182 of the informal economy to for example GDP relate to definitional debates over what 183 needs to be included within such measures as well as methodological debates over 184 how it should be calculated (Chen, 2012; Kanbur, 2009; Ligthelm, 2006; Saunders \& 185 Loots, 2005). For this reason, estimates of the size and monetary value of informal 186 activities that contribute to a green economy are not forthcoming, falling outside of 187 the scope of this paper.

188 Furthermore, perceptions about the informal economy influence its conceptualisation 189 and 'management'. Chen $(2007 ; 2012)$ distinguishes between four schools of thought 190 pertaining to the nature and composition of the informal economy, whereas Williams 191 (2007) problematises the dominant paradigms regarding 'formalisation', 192 'commodification' and 'globalisation' in terms of their estimation of and approach to 193 informal livelihood activities. Globally, perspectives regarding the informal economy 194 have changed progressively (see Table 2). 
Table 2: Changes in perspectives on the informal economy

The old view The new view

The informal sector is the traditional The informal economy is 'here to stay' and expanding with economy that will wither away and modern industrial growth.

die with modern, industrial growth.

\begin{tabular}{|l|l|}
\hline It is only marginally productive. & It is a major provider of employment, goods and services for
\end{tabular} lower-income groups.

It contributes a significant share of GDP.

It exists separately from the formal It is linked to the formal economy-it produces for, trades with, economy. distributes for and provides services to the formal economy.

It represents a reserve pool of surplus Much of the recent rise in informal employment is due to the labour. decline in formal employment or to the informalisation of previously formal employment relationships.

It is comprised mostly of street It is made up of a wide range of informal occupations-both traders and very small-scale 'resilient old forms' such as casual day labour in construction producers. and agriculture, as well as 'emerging new ones' such as temporary and part-time jobs plus homework for high tech industries.

Most of those in the sector are entrepreneurs who run illegal and unregistered enterprises in order to avoid regulation and taxation.

It is made up of non-standard wage workers as well as entrepreneurs and self-employed persons producing legal goods and services, albeit through irregular or unregulated means. Most entrepreneurs and the self-employed are amenable to, and would welcome, efforts to reduce barriers to registration and related transaction costs and to increase benefits from regulations; and most informal wage workers would welcome more stable jobs and workers' rights.

Work in the informal economy is Informal enterprises include not only survival activities but comprised mostly of survival activities and thus is not a subject for economic policy.

Source: Chen (2007:5). also stable enterprises and dynamic growing businesses, and informal employment includes not only self-employment but also wage employment. All forms of informal employment are affected by most (if not all) economic policies.

The informal economy manifests heterogeneously, ranging from small and micro

199 survivalist business activities in public and private settings, such as pavements, 200 pedestrian malls, transport interchanges and homes, to agrarian activities found in 201 both urban and rural areas (Chen, 2012; Devey et al., 2003; Du Toit \& Neves, 2013; 202 Horn, 2011; Kanbur, 2009; Skinner, 2008; Wills, 2009). Although the informal 203 economy cuts across divisions of race, class and gender, several studies have shown 204 that the majority of actors are black, impoverished and female (Du Toit \& Neves, 205 2012; Horn, 2011; Skinner, 2008). This has led authors such as Musyoki (2012) and 
207 vast opportunities for sustainable and 'just' development as interventions in the

208 informal economy may help to uplift the poorest and most disenfranchised.

210 Chambwera et al. (2011) suggest that the informal economy offers much value in

211 delivering sustainable development ideals, including the green economy. Government

212 planners, donors and nongovernmental organisations (NGOs) therefore need to 213 consider the informal economy alongside the formal economy if they plan to "help lift 214 up the wellbeing of the poor and address global challenges such as climate change" 215 (Chambwera et al., 2011).

217 The South African approach to the informal economy, however, indicates reluctance 218 in recognising this value (Smit \& Musango, Forthcoming).

\section{The informal economy in South Africa}

221 The South African government defines the second economy as the 'range of activities 222 that are often marginal, outside the regulatory net and survivalist in character' (EDD, 223 2013). The notion of two economies was first introduced by former President Thabo

224 Mbeki in 2003, who recognised the 'structural disjuncture' between the modern, first225 world economy and the underdeveloped third-world or 'second' economy (Mbeki, 226 2003). The divide between the 'two economies' is systemic and associated with 227 several key apartheid legacies that relate to the (i) centralised monopoly structure of 228 the core economy; (ii) distorted nature of asset distribution, including capital, land and 229 human capital development; and (iii) spatial legacies of bantustans and apartheid 230 cities (TIPS, 2009). 
232 The second economy is recognised as having several debilitating characteristics,

233 giving rise to the perception that it requires fixing, elimination or formalisation

234 (Mbeki, 2003; Gumede, 2008). South Africa's response to the informal economy

235 includes the Second Economy Strategy released in 2009, which headlines 11 priority

236 areas (TIPS, 2009). Additionally, the New Growth Path focuses on growth (including

237 'green growth') as a means of addressing poverty, unemployment and inequality in 238 South Africa.

240 The Economic Development Department was established to coordinate the

241 development of the New Growth Path and to promote coherent economic 242 development (EDD, 2013). Under this mandate, the Department's programme for 243 Economic Policy Development includes the second economy as a sub-programme, 244 which aims to 'develop policies that will transform second economy activities into 245 dynamic, competitive activities that are part of the economic mainstream' (EDD, 246 2013).

248 In contrast, the green economy is considered to be a sub-programme of a separate 249 programme related to Economic Planning and Coordination (EDD, 2013). This 250 separation of the second economy and green economy as detached sub-programmes 251 may be indicative of the general disconnect between policies and plans related to the 252 green economy and the informal economy.

\section{Connecting the green and the informal economy}

255 The informal economy is 'an important component in the social, economic and 256 political arenas of Africa' (Dawa \& Kinyanjui, 2012) and several traits are recognised 
257 as being significant to creating an 'inclusive green economy'. These include the 258 following:

(i) Formal-informal linkages

261 The majority of informal economy operations are connected to the formal sector

262 through a range of forward and backward linkages and complex interactions (Davies 263 \& Thurlow, 2010; Chambwera, et al., 2011; Chen, 2012). These linkages include

264 individual transactions through open market exchanges; production and exchange of 265 goods; value chains (Chen, 2012:12); and the flow of raw materials, equipment and 266 finance (Chambwera et al., 2011).

(ii) Regulating for economic diversity

269 The formal regulatory environment in general often ignores entire categories of the 270 informal economy, leading to a number of adverse effects, as described by Chen 271 (2012). Chen subsequently argues for a more comprehensive approach to formalising 272 the informal economy. Such an approach would also require reconsideration of 273 macro-economic policies specific to the informal economy, as described by Saunders 274 \& Loots (2005): ...the results of the causality test suggested that macro-economic policies aimed at the formal economy will not necessarily 'trickle down' to the informal economy, while macro-economic policies aimed at the informal economy may well have a profound effect on the formal economy.

280 The informal economy offers an alternative to the neoliberal economic model, having 281 a broader range of objectives, including being reproductive; sustaining household 282 survival; and facilitating social connectedness (Du Toit \& Neves, 2012). 
283 Chen (2012) suggests that a new economic paradigm or 'hybrid economy' is needed 284 that is open to such duality; embraces both 'the traditional and the modern, the small 285 scale and the big scale, the informal and the formal'; addresses power imbalances; and 286 protects the vulnerable.

288 Samers (2005) in contrast, suggests that informal economies do not always lend 289 themselves to systems of reciprocation and obligation, and at times even involve 290 exploitative and illegal activities. Indeed, the informal economy constitutes a broad 291 spectrum of activities ranging from legal to illegal (Chen, 2012) and can be a source 292 of both environmental restoration (Blignaut et al., 2008) and destruction (Biswas et 293 al., 2012). However, these issues cannot be ignored, and policies and plans that tie 294 green and informal economies together should aim not only to maximise 295 environmentally protective or restorative activities, but also to minimise 296 environmentally destructive and exploitative activities.

(iii) Employment potential

299 Chen (2012) describes informal employment as a growing reality in the global 300 economy, constituting the main source of income for most people in the developing 301 world. It is thus argued that the informal economy should be better recognised and 302 integrated into economic planning and legal frameworks (Chambwera et al., 2011; 303 Chen, 2012; Dawa \& Kinyanjui, 2012).

305 Although the size of the informal sector is markedly lower for South Africa (Davies \& 306 Thurlow, 2010), its role in providing a buffer between employment and 
unemployment in times of financial crisis cannot be underestimated (TIPS, 2009; Chambwera, 2011).

311 Informal economies produce networks of 'trust and morality', which are embedded

312 within the socio-cultural environment (Du Toit \& Neves, 2012). Informal actors are 313 also closely linked to their communities, hence 'providing valuable networks for

314 resource management, energy requirements and climate change' (Chambwera, 2012).

316 Whilst such networks may induce conflict, tension and skewed exchanges, they are 317 also significant in enabling the poor 'to mitigate poverty and the effects of 318 vulnerability', acting as a form of 'private social protection' (Du Toit \& Neves, 2007).

An 'inclusive green economy' would require greater networks of dynamic interaction 321 and collaboration that transcend the formal-informal divide, as described by 322 Torgerson (2001). Green thinking need not consider formal and informal economies to be either/or alternatives. The two can be seen as potentially complementary aspects of a complex, political process of radical reform beyond the control of any single agent responsible for achieving a green economy.

(v) Sites of resilience and opportunity

330 Informal actors leverage and supplement their meagre domestic resources to cope 331 with shocks and sustain informal economic activities (Du Toit \& Neves, 2007), 
332 thereby acting as sites of resilience and possibility. Vermeulen et al. (2008) illustrate

333 how impoverished local communities found innovative ways of coping with changes

334 in weather patterns. This led Vermeulen et al. (2008) to suggest that supporting such

335 local initiatives and institutions may be a more effective strategy for adapting to

336 climate change than relying on top-down initiatives only.

(vi) Connection with ecological services

339 There is a deep connection between rural livelihoods and ecological services 340 (Musyoki, 2013). In most instances, areas of high ecosystem goods and services 341 provision in South Africa have strong association with 'pockets of poverty' (Blignaut 342 et al., 2008).

344 Rural and poor communities may also benefit from the development of markets for 345 ecosystem goods and services (Blignaut et al., 2008). Linking the ecosystem services 346 'supply' activities performed by the rural poor to the demand in urban environments 347 may result in employment opportunities, whilst positively impacting conservation 348 efforts and reducing demand for social welfare (Blignaut et al., 2008).

351 The actors, agents and entities operating in the informal economy are neither shielded 352 from nor indifferent to the effects of climate change; instead producing alternative 353 coping strategies (Dawa \& Kinyanjui, 2012; Raghupathy \& Chaturvedi, 2013). A 354 number of households and communities in Africa are implementing green livelihood 355 strategies, which include the adoption of household scale energy technologies, organic 356 waste management, and urban farming (Acey \& Culhane, 2013). Smit and Musango 
357 (Forthcoming) identified green activities that are recognised by several green economy practitioners and policy advisors as contributing to an inclusive green economy' in South Africa. These include among others bioprospecting and biotrade; recycling and waste picking; and the use of green infrastructure, technology and

361 construction.

These informal green activities are recognised as coping strategies, which are also

364 akin to green jobs (DEA, 2014). However, current debates about 'green jobs' are

365 silent about the 'everyday practice of green livelihoods carried out by the urban poor', 366 instead focusing on large-scale, formal sector responses (Acey \& Culhane, 2013).

367 Such approaches are considered to be problematic as they obscure the transformative 368 value of small-scale technologies and ignore the contribution of the informal 369 economy.

371 A further issue concerning green jobs relates to the conditions and quality of the 372 employment (Montmasson-Claire, 2012). 'Green' employment is not decent by 373 definition and therefore will 'require careful stewardship from public authorities to 374 ensure workers are able to exercise their rights' (Cunniah, 2012). Waste pickers for 375 example reportedly operate in 'hostile' social environments, are vulnerable to 376 exploitation by middlemen, and are exposed to tremendous health and safety risks 377 (Jones, 2013). Such challenges need to be addressed by national policy strategies in 378 order to build 'a just transition towards an environmentally respectful and socially 379 empowering economy' (Olsen, 2012). 
7. Policy approaches and intervention criteria towards connecting the green economy with the informal economy

383 The formulation of policies and plans to connect the informal economy with the green 384 economy requires an understanding of the informal economy that extends beyond 385 assumptions that informal activities are unorganised and chaotic in form or practice.

386 Policy interventions taking this stance have often resulted in disaster as they negate 387 the value of the community structures that are in place (Guha-Khasnobis et al., 2006). 388 For this reason, Guha-Khasnobis et al. (2006) advocate an approach that recognises 389 complexity and contextual realities, and suggest that several evaluative criteria be 390 incorporated when planning for the informal economy in general, including:

(i) Subsidiarity in a multi-level system

393 Rather than engaging in the dialectic between the centralisation or de-centralisation of 394 government agency, each intervention should be located 'as close as possible to where 395 it is meant to influence markets or groups' (Guha-Khasnobis et al., 2006). At the same 396 time, interventions should be embedded within a larger system of government.

(ii) Balance between 'formal' interventions and 'informal' practices

399 There is a need for balancing 'formal' rules with the 'fine-tuning' of 'informal' rules 400 and norms; a process that necessitates an in-depth, participatory approach.

(iii) Implementation capacity

403 Interventions need to be designed to match both the implementation capacity of 404 government and the absorptive capacity of the recipients. In some instances this may 

making processes and the empowerment of workers by strengthening and supporting

418 informal worker organisations (Chen, 2012). 'Visibility' may be addressed through

419 improved measurement and representation in statistics, whereas 'validity' involves economy.

\section{Conclusion}

425 The notion of an 'inclusive green economy' is highly contested, with interpretations ranging from narrow to broad. Narrow interpretations limit participative and

427 transparent processes, and continue to reproduce and exacerbate inequality and 428 injustice. In contrast, broader interpretations value the social dimension of sustainable 429 development and incorporate democracy and transparency into its processes. 
430 Moreover, such broader interpretations engage with institutional issues of power and

431 participation and focus on resilience and the creation of sustainable livelihoods. It is

432 argued that a broader interpretation of the green economy in general, and green jobs

433 in particular, is required for the transition to an 'inclusive green economy' to

434 transpire.

435

436 For South Africa, such a transition implies an approach that engages with its

437 contextual realities, whilst at the same time addressing issues such as vested interests,

438 institutional arrangements, and poor policy integration and implementation. For the

439 South African green economy to be inclusive and socially just, it would need to

440 engage with the mass of disenfranchised individuals in a way that empowers and

441 reinforces participation and sustainable livelihoods. Furthermore, it may be argued

442 that a more open and enabling policy environment could greatly assist the transition to

443 an alternative economic model, which may be more conducive to socially equitable

444 and environmentally sustainable development. The literature review in this paper

445 provided the basis for empirical analysis, which is found elsewhere in Smit and

446 Musango (Forthcoming).

447 Acknowledgement

448 This work was supported by funds received from the National Research Foundation's

449 Community Engagement Programme awarded to Stellenbosch University

$451 \quad$ References

452 Acey, CS \& Culhane, TH, 2013. Green jobs, livelihoods and the post-carbon 453 economy in African cities. Local Environment: The International Journal of $454 \quad$ Justice and Sustainability 18(9), 1046-65. 
Allen, C, 2012. A Guidebook to the Green Economy. Issue 3: Exploring green economy policies and international experience with national strategies. http://sustainabledevelopment.un.org/index.php?page=view \&type=400\&nr=738 $\& m e n u=35$ Accessed 7 January 2014.

Allen, C \& Clouth, S, 2012. A Guidebook to the Green Economy. Issue 1: Green Economy, Green Growth, and Low-Carbon Development-history, definitions and a guide to recent publications.

http://www.uncsd2012.org/content/documents/ 528Green\%20Economy\%20Guidebook_100912_FINAL.pdf Accessed 7 January 2014.

AtKisson, A, 2013. Green Economy 2013: A strategic briefing on the state of play in the global transition. http://atkisson.com/greeneconomy.php Accessed 15 January 2014.

Biswas, AK, Farzanegan, M.R., \& Thum, M. 2012. Pollution, shadow economy and corruption: Theory and evidence. Ecological Economics 75, 114-25.

Blignaut, J, Marais, C, Rouget, M, Mander, M, Turpie, J, Klassen, T, \& Preston, G, 2008. Making Markets work for People and the Environment: Employment Creation from Payment for Eco-Systems Services. www.tips.org.za/files/EGS_report_-_18_Nov.pdf Accessed 8 February 2014.

Boehnert, J, 2013. Re-imagining the Commons as 'The Green Economy'. https://www.academia.edu/3294072/Re-Imaging_the_Commons_as _The_Green_Economy. 
Accessed 10 January 2013.

481 Buehn, A \& Schneider, F, 2012. Shadow economies around the world: novel insights, accepted knowledge, and new estimates. International Tax and Public Finance 19, 139-71.

484 485

Chambwera, M, MacGregor, J \& Baker, A, 2011. The Informal Economy: A primer for development professionals on the importance of the informal economy in developing countries. http://pubs.iied.org/15515IIED.html?b=d Accessed 23 November 2013.

Chambwera, M. 2012. The informal economy - a threat or driver for the green economy? http://www.greeneconomycoalition.org/know-how/informaleconomy-threat-or-driver-green-economy Accessed 27 February 2014.

Chen, MA, 2007. Rethinking the Informal Economy: Linkages with the Formal Economy and the Formal Regulatory Environment. UNDESA Working Paper No. 46. http://www.un.org/esa/desa/papers/2007/ wp46_2007.pdf Accessed 13 February 2014.

Chen, MA, 2012. The Informal Economy: Definitions, Theories and Policies. Women in Informal Employment: Globalizing and Organizing (WIEGO), Working Paper 1, Manchester, UK.

Clapp, J \& Dauvergne, P, 2011. Paths to a Green World: The Political Economy of the Global Environment. 2nd edn. Cambridge, Massachusetts.

Cook, S, Smith, K \& Utting, P, 2012. Green Economy or Green Society? Contestation and Policies for a Fair Transition. UNRISD Occasional Paper Ten, Social 
Dimensions of Green Economy and Sustainable Development, UNRISD \& Friedrich Ebert Stiftung, November.

506 Cunniah, D, 2012. Forward. Are 'green' jobs decent? International Journal of Labour Research 4(2), 133-4.

Daly, H, 2011. From a failed growth economy to a steady-state economy. In UNCTAD (2011). Road to Rio+20: For a development-led green economy, Issue 1. http://unctad.org/en/Docs/ditcted20108_en.pdf Accessed 8 January 2014.

513 Davies, R \& Thurlow, J, 2010. Formal-informal economy linkages and unemployment in South Africa. Southern African Journal of Economics 78(4),

Dawa, FO \& Kinyanjui, MN, 2012. Green Economy and Sustainable Development: Which Way for the Informal Economy? $437-58$.

\section{1} http://www.unrisd.org/unrisd/website/newsview.nsf/\%28http News\%29/43B2464B82F227A1C1257A41002D14B2?OpenDocument. Accessed 15 November 2013.

DEA (Department of Environmental Affairs), 2014. About Green Economy. https://www.environment.gov.za/projectsprogrammes/greeneconomy/

DEA (Department of Environmental Affairs) and UNEP (United Nations Environmental Programme), 2013. Green economy modelling report for South Africa (SAGEM): focus on the sectors of Natural Resource Management, Agriculture, Transport and Energy. 
https://www.environment.gov.za/sites/default/files/docs/greeneconomy_modeli ngreport.pdf Accessed 19 September 2013.

Dercon, S, 2012. Is Green Growth Good for the Poor? World Bank Policy Research Working Paper 6231. http://elibrary.worldbank.org/doi/book/10.1596/1813-9450-6231. Accessed 12 January 2014.

Devey, R, Skinner, C \& Valodia, I, 2003. Informal economy employment data in South Africa: A critical analysis. Cape Town: Development Policy Research Unit.

Dreher, A \& Schneider, F, 2010. Corruption and the shadow economy: an empirical analysis. Public Choice 144, 215-38.

541 Du Toit, A \& Neves, D, 2007. In search of South Africa's second economy: Chronic poverty, vulnerability and adverse incorporation. In Mt. Frere and Khayelitsha. Programme for Land and Agrarian Studies (PLAAS) Working Paper 1. http://www.plaas.org.za/plaas-publication/wp-1 Accessed 6 February 2014.

Du Toit, A \& Neves, D, 2012. Money and sociality in South Africa's informal economy. Africa 82(1), 131.

Du Toit, A \& Neves, D, 2013. Rural Livelihoods in South Africa: Complexity, Vulnerability and Differentiation. Journal of Agrarian Change 13(1), 93-115.

EDD (Economic Development Department), 2010. The New Growth Path: The Framework. Pretoria.

552 EDD (Economic Development Department), 2013. Programmes 2 and 3.

553 http://www.economic.gov.za/about-us/programmes 
Accessed 4 February 2014.

555

556

Guha-Khasnobis, B, Kanbur, R \& Ostrom, E, 2006. Beyond Formality and Informality. In Guha-Khasnobis, B, Kanbur, R and Ostrom, E (Eds.), Linking the Formal and Informal Economy: Concepts and Policies. Oxford University Press, New York.

Gumede, V, 2008. Poverty and 'Second Economy' in South Africa: An Attempt to Clarify Applicable Concepts and Quantify Extent of Relevant Challenges. Development Policy Research Unit Working Paper 08/133. www.dpru.uct.ac.za/sites/default/files/image.../ DPRU\%20WP08-133.pdf Accessed 5 February 2014.

Horn, A, 2011. Who's out there? A profile of informal traders in four South African city central business districts. Town and Regional Planning, 2011(59):1-6.

ILO (International Labour Organization), 2003. Report of the Seventeenth International Conference of Labour Statisticians, Geneva, 24 November - 3 December 2003, Geneva ILO.

ILO (International Labour Organization), 2012. Statistical update on employment in the informal economy. http://laborsta.ilo.org/applv8/data/INFORMAL_ECONOMY/2012-06Statistical\%20update\%20-\%20v2.pdf Accessed 23 April 2014.

Jones, G, 2013. Waste collectors face tough conditions. http://www.financialmail.co.za/fm/Features/2013/07/04/waste-collectors-facetough-conditions Accessed 10 March 2014.

Kanbur, R, 2009. Conceptualizing informality: Regulation and enforcement. Indian 
Journal of Labour Economics, February 2009:1-12.

580

Ligthelm, AA, 2006. Size estimate of the informal sector in South Africa. South African Business Review, 10(2): 32-52.

Maia, J, Giordano, T, Kelder, N, Bardien, G, Bodibe, M, du Plooy, P, Jafta, X, Jarvis, D, Kruger-Cloete, E, Kuhn, G, Lepelle, R, Makaulule, L, Mosoma, K, Neoh, S, Netshitomboni, N, Ngozo, T, Swanepoel, J, 2011. Green Jobs: An Estimate of the Direct Employment Potential of a Greening South African Economy. Johannesburg, Midrand and Pretoria, IDC, DBSA and TIPS.

Mbeki, T, 2003. Letter from the President: Meeting the challenge of the second economy. ANC Today 3 (45). http://www.anc.org.za/docs/anctoday/2003/at45.htm Accessed 6 February 2014.

Montmasson-Clair, G, 2012. Green Economy Policy Framework and Employment Opportunity: A South African Case Study. (TIPS) Working Paper Series, Pretoria, South Africa.

Musyoki, A, 2012. The emerging policy for Green Economy and Social Development in Limpopo, South Africa. UNRISD Occasional Paper Eight: Social Dimensions of Green Economy and Sustainable Development. United Nations Research Institute for Social Development \& Friedrich Ebert Stiftung, June.

Nhamo, G, 2013. Green economy readiness in South Africa: A focus on the national sphere of government. International Journal of African Renaissance Studies Multi-, Inter- and Transdisciplinarity 8(1), 115-42.

Olsen, L, 2012. What policies for a green economy that works for social progress? International Journal of Labour Research 4(2), 135-49. 
603 Peter, C \& Swilling, M, 2011. Greening the South African Growth Path: Transitioning to Sustainability. Prepared for the DBSA, Pretoria.

Raghupathy, L and Chaturvedi, A, 2013. Secondary resources and recycling in developing economies. Science of the Total Environment 461-462, 830-34.

Rogerson, CM, 2007. 'Second economy' versus informal economy: A South African Affair. Geoforum 38, 1053-57.

Samers, M. 2005. The myopia of "diverse economies", or a critique of the "informal economy". Antipode, 37(5):875-886.

Saunders, S \& Loots, E, 2005. Measuring the informal economy in South Africa. South African Journal of Economic and Management Sciences 8(1), 92-101.

Schepelmann, P, Goossens, Y, \& Makipaa, A (Eds.), 2010. Towards Sustainable Development: Alternatives to GDP for measuring progress. Wuppertal Institute for Climate, Environment and Energy, Wuppertal Special no. 42. http://wupperinst.org/en/publications/details/wi/a/s/ad/1113 Accessed 16 January 2014.

Skinner, C, 2008. Street trade in Africa: A review. Women in Informal Employment:

620 Smit, S \& Musango, JK, Forthcoming. Exploring the connections between green economy and informal economy in South Africa. Paper resubmitted for Publication to South African Journal of Science, 20 January 2015 [Manuscript

624 Smith, R, 2011. Green Capitalism: The god that failed. Real-World Economics Review 56(March), 112-44.

626 Söderbaum, P, 2013. Ecological economics in relation to democracy, ideology and politics. Ecological Economics 95, 221-5. 
Southall, R, 2010. The South African Development Model: Hitting against the limits. Strategic Review for Southern Africa 32(2), 69.

Sustainlabour. 2013. Green Jobs and related policy frameworks: An overview of South Africa. http://www.tips.org.za/files/green_jobs_and_relatedpolicy_frameworks__overview_south_africa.pdf Accessed 8 February 2014.

TIPS (Trade and Industrial Policy Strategies), 2009. Second Economy Strategy: Addressing Inequality and Economic Marginalisation. http://www.tips.org.za/files/Second_Economy_Strategy_Framework_Jan_09_0. pdf Accessed 6 February 2014.

Torgerson, D, 2001. Rethinking politics for a green economy: A political approach to radical reform. Social Policy and Administration 35(5), 472-89.

UNDESA (United Nations Department of Economic and Social Affairs), 2014. Green economy in the context of sustainable development and poverty eradication. http://sustainabledevelopment.un.org/index.php?menu=1224 Accessed 6 January 2014.

Vermeulen, S, Dossou, K, Macqueen, D, Walubengo, D, \& Nangoma, E, 2008. Springing back: climate resilience at Africa's grassroots. Sustainable Development Opinion, http://pubs.iied.org/17038IIED.html?a=S\%252520Vermeulen Accessed 10 February 2014.

Williams, CC, 2007. Rethinking the Future of Work: Directions and Visions. Palgrave Macmillan, New York. 
653 Wills, G. 2009. South Africa's informal economy: A statistical profile. Women in 654 Informal Employment: Globalizing and Organizing (WIEGO), Working Paper 655 6. Manchester, UK. 